UDC -044.9. 629.7.05

Kovalenko Yu.B., orcid.org/0000-0002-6714-4258, Kozlyuk I.O.,

orcid.org/0000-0001-8239-8937

\title{
DESIGNING OF TECHNOLOGICAL PROCESSES OF DECISION- MAKING SUPPORT INFORMATION SYSTEM IN INTEGRATED MODULAR AVIONICS
}

\author{
National Aviation University \\ yleejulee22@gmail.com \\ avia_ira@ukr.net
}

\section{Introduction}

In order to enter the world market, products and their production must undergo international certification, confirming its quality and high specifications. At the same time, certification is subject not only to the product itself, but also to methods of its design, manufacture, methods and forms of product information transmitting and etc. Requirements for providing the necessary information are associated with modern standards for technical documentation, for which the basic creation environment, storage and exchange is electronic space.

One of the conditions for the implementation of these requirements is the creation of a quality management system (QMS), which ensures the fulfillment of modern requirements of international standards in product development, preparatory and production processes and certification of companies according to these standards.

Preparation of serial production should be carried out on the basis of a complete electronic description of the product design [5].

The technological design system should provide:

- possibility of parallel design and technological design of products projection in a digital information environment in the conditions of transition to unplanned preparation of production and organization of electronic document circulation;

- usage of an electronic design model of a product as initial data for the design of technological processes and technological equipment;

- technological electronic models formation of products and their usage for modeling and visualization of technological processes;

- working areas of assembly units analysis using electronic models of assembly equipment and anthropometric models of performers;

- technological documentation set formation; the formation and maintenance of the information environment of assembly work. \section{statement}

Literature analysis and problem

The process of designing technological processes for information support for decision-making in integrated modular avionics for modern aircraft is a complex multi-stage procedure, the implementation of which involves the cooperation of aviation industry enterprises with a rigid distribution of tasks and responsibilities. In this regard, the United States and Europe pays great attention to improving the aircraft design and certification process. In accordance with global trends, the process must meet a number of requirements and standards. The issues of development and certification of highly integrated complex systems installed on aircraft, taking into account their operation and performed functions, are set out in the following guidelines: ARP4754A (USA), ED-79A (EU). These documents cover the full life cycle of systems that provide the implementation of functions 
at the aircraft level. Software development issues are stated in documents: DO-178C (USA), ED-12C (EU), and hardware design in documents: DO-254 (USA), ED-80 (EU). To assess the safety of equipment used: ARP 4761 (USA), ED-135A (EU). After analyzing the literature [1-4] and standards, we can formulate the goal and objectives of the study

\section{the study \\ The purpose and objectives of}

Objective: To review the Integrated Modular Avionics (IMA) architecture and standards that enabled the development of an ARINC 653 compliant commercial off-theshelf (COTS) real-time operating system (RTOS) and support for multi-core processor architecture.

Tasks: to formulate requirements for the system; implement a configuration management process; distribute responsibility and scope of work between suppliers; assess and implement all safety requirements at all levels of development; ensure high-quality work performance; generate documentation that meets all the requirements for aircraft certification; build the right relationship between aircraft manufacturer and suppliers in a market economy.

In the area of CALS / IPI research technology and close to it areas, there are known works of a number of foreign and domestic scientists, among which are Sudova E., Levina B., Ivanova V., Yatskevich A., Bakakova V., Tsirkova A.

The issue of decision-making in integrated systems for ensuring the quality of design technological solutions is considered crucial. So Glichev A. in his work "Fundamentals of product quality management" writes "The quality of decisions taken determines the effectiveness of the quality system".

The works of domestic and foreign scientists are devoted to questions of multi-criteria and the choice of an alternative in technics, such as Brahman T., Saati K., Kern K., Volchenkov A., Shvetsov A., Kozlov N., Fedyukin V., Durnev V, et al.

Therefore, the next stage in the development of systems for technological preparation of production is their integration with systems of automated design of technological processes (CAD) and expert systems for evaluating and making more reasonable decisions based on multi-criteria optimization of design and technological solutions.

$\mathrm{CAD}$ is an important factor in accelerating the processes of technological design and improving their quality based on the continuity of standard technological solutions [6].

One of the most important stages of the life cycle of complex science-intensive products is the stage of its development, a stage when the quality of the future product is laid down in foundation [7]. To manage the quality of the designed product it is very important to have tools that allow you to measure the quality of the product, especially at the design stage of its life cycle.

At present, quality assessment is one of the most important tasks in examination of technical systems.

Examination of design solutions plays an important role in quality management of new equipment developing process, the main task of which is to ensure the competitiveness of new equipment. If the creation of new techniques in the aviation industry is oriented on the scientific and technological progress achievements usage and the decisions made at each stage of the life cycle of the technical system are sufficiently substantiated, then the high quality of such a technical system may be guaranteed. According to this task, quality management consists, first of all, in verifying the validity of decisions made.

An imperfect project, under no circumstances, will not ensure high quality products. Analysis and assessment of the validity of design solutions are assigned to the examination of projects.

The essence of examination as a scientific method is the rational organization of expert analysis of the problem with a quantitative assessment of judgments and processing of results. Expert opinion is taken as a solution of the problem solving. The whole variety of tasks solved by experts comes down to two types: system analysis of the project proposal and parametric analysis. System 
analysis aims to confirm the feasibility (or inappropriateness) of creating a new model of equipment, to evaluate its technical level and economic efficiency, taking into account the requirements and capabilities of a higherlevel technical system. The parametric analysis of the project proposal lies in the rationale of the credibility of design parameters and characteristics of the technical system, their ability to be realized, the importance of targeted tasks.

The purpose of the work is to develop methodological support and software for formation and examination of design technological proposals for materialization of complex technical systems of aircraft.

We shall understand that a decisionmaking process is the process of choosing the optimal solution among alternative options.

A decision support system is a combination of software, simulation, statistical and analytical models of processes and work on the project to prepare decisions on its implementation.

The purpose of decision-making support information system is an organization and management of decision-making in the development and implementation of projects based on modern information processing technologies [8-10].

\section{Life cycle of the project and man- agement functions}

The structure of integrated decisionmaking support information system is largely determined by the structure of management processes taken within the organization. As a result, it can be structured by:

- stages of the project cycle;

- functions;

- levels of management.

The enlarged project life cycle and management functions associated in connection with various stages of a project are shown in Fig. 1. A different information support and software are used to support different management functions. At the stage of project implementation, it is necessary to provide the collection of actual data on the state of works in order to present them optimally for analysis and ensure the exchange of information and interaction between project participants.

The most important component of integrated decision-making support information systems is database management systems (DBMS). Their main functions are to support the integrity, security, archiving and synchronization of data in terms of many users work.

Aviation industry is actively implementing advanced CALS / IPI technologies. In the context of the concept of CALS / IPI technologies, quality management methods are gaining new development. The use of an integrated information environment provides information support and integration of processes, and consequently the ability to use electronic data created during various company's processes for quality management tasks at all stages of a life cycle (LC) of a complex knowledge-intensive product (technical system) [11].

One of the goals of realization CALS / IPI technologies concept is ensuring the required product quality, so quality management system (in terms of ISO 9001-2000 series standards) is related to the basic management technologies.

Quality management in a broad sense must be understood as processes management aimed at ensuring the quality of their results. This approach corresponds with ideas of general quality management, the essence of which is precisely management of a company through quality management [12].

\section{Models of designing process}

From the point of view of a system approach, designing can be considered as a process of special information transformations on a basis of some design condition of a product into final result of the project (technological - information image of production of this product) by means of mechanisms and in the presence of a number of restrictions (Fig. 2). Many models that differ in the composition of information objects, relationships and properties are formed during designing process.

The results of technological design are information model of product materialization [12]. 
These models differ from each other in the composition of information objects, relationships and product properties (SI). Information about product properties is transmitted to the upper management level, where, generated in the next stage of the LC properties and its values comparison is conducted with properties and values recorded in the previous stage and are requirements for the current stage. The identified differences in the properties indicated on the diagram by symbols D,

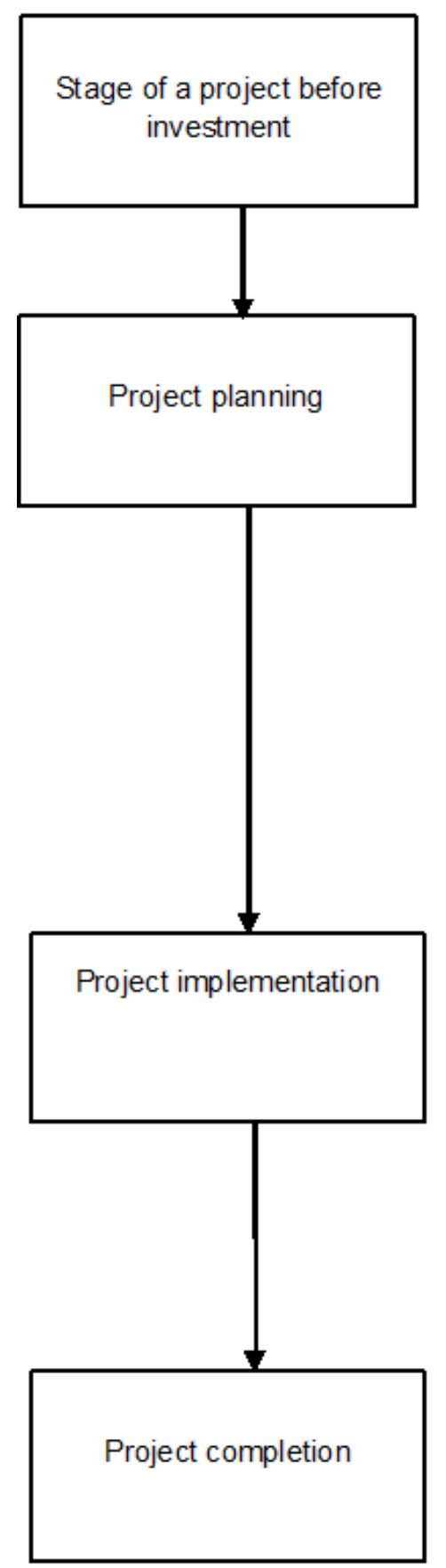

serve as control signals, on a basis of which the course of main processes is adjusted.

The dashed lines on the diagram show influence on design processes associated with deviations from the requirements identified on the next stages of LC. This essentially displays an experience usage, accumulated during the product design, production and operation processes and is implemented through a quality assurance system.

- Justification of project
objectives
- Assessment of economic
efficiency of a project in
general

- Detailed planning of complex of works and resources

- Analysis of project deadlines in general and its individual stages

- Resource planning, analysis and optimization of a project resource allocation schedule

- Analysis of costs, project needs in financial resources, cost planning

- Monitoring of a project
progress
- Analysis of a project status
- Operational project
management
- Project redevelopment
- Reporting and
documenting of work
progress

Project management
software
Group work support
software
Reporting software
Document flow and
archiving systems

Financial analysis and statistical planning software

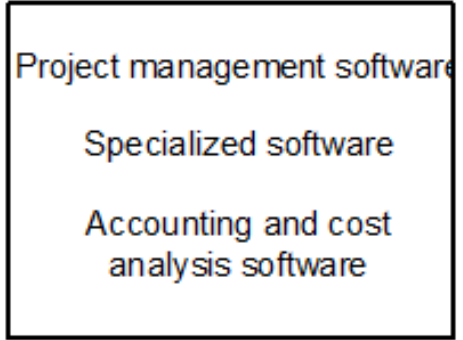

- Reporting and documenting of project results

Fig. 1. Types of software for various stages of a project 
The dash-dotted lines show the impact of design and technological data on resource creation processes.

The quality of technological design of a complex product significantly affects the quality of produced products. Numerous errors and shortcomings that occur in existing design methodology, as well as waste of time, can be significantly reduced if during the project creation will be used:

- modern automated synthesis and analysis systems of the created technological project; technological knowledge bases and expert systems that allow you to provide designers with new and reliable information about technological achievements quickly;

- automated decision-making systems that allow you to optimize technological decision-making for each level and stage of the life cycle of the technological project;

- automated configuration management systems of the technological project;

- automated systems of control, management and provision of technological solutions and technological documentation;

- simulation systems;

- project communication management systems.

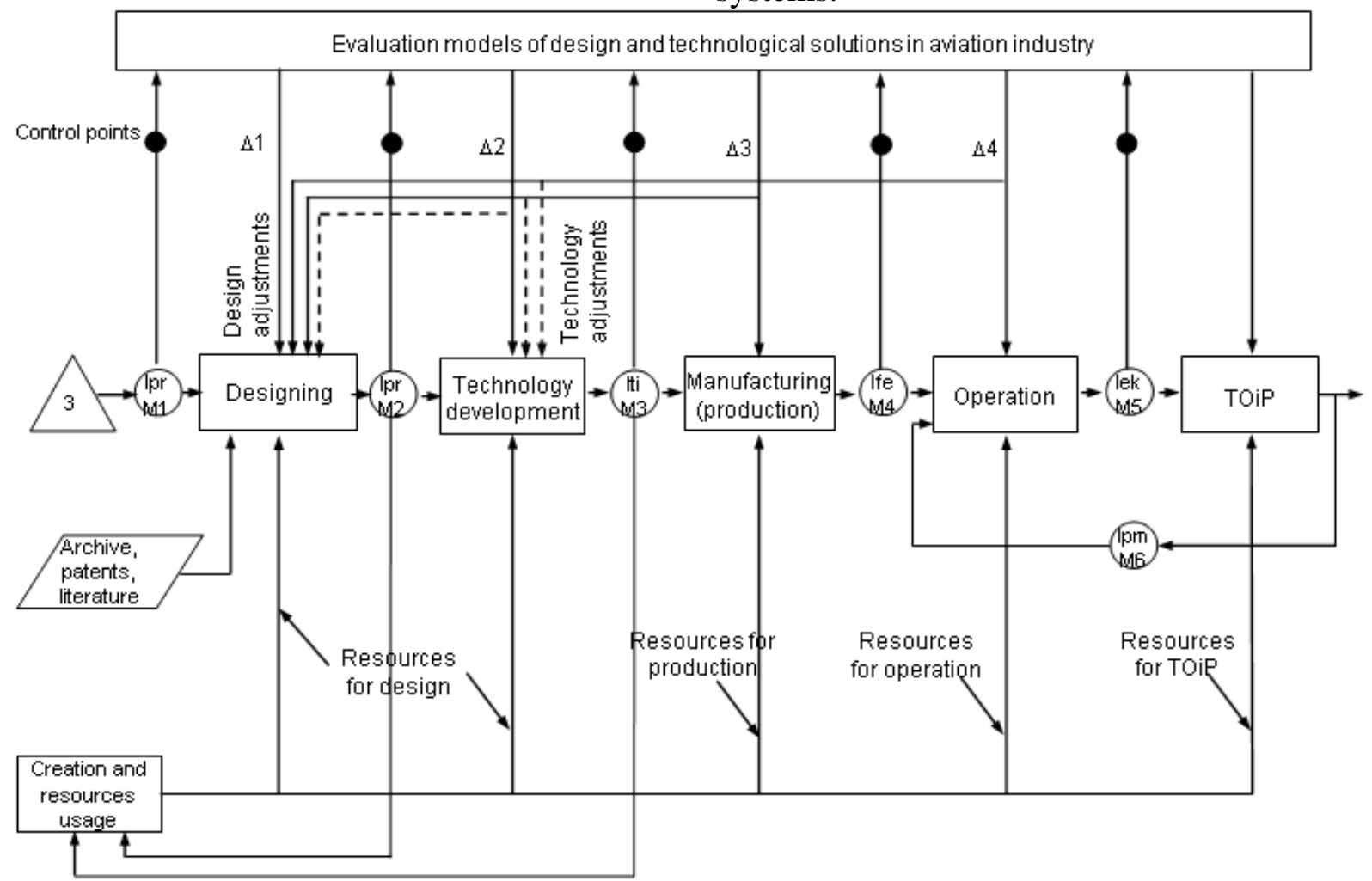

Fig. 2. The project in aviation industry as a process of transition of a system from initial state to the final one and a process of transforming information models during a life cycle

In the future, such systems and subsystems can be combined into unified information systems of automated creation of a technological project based on CALS / IPI technologies and will actually serve as components of a technological project quality assurance system. That is, to create a high-quality technological project, it is necessary to use more advanced design mechanisms or a special set of tools.
Communication and information support of designing process

Project communication management is a management function aimed at ensuring the timely collection, generation, distribution and storage of necessary project information.

Information is a collected, processed and distributed data. In order to be useful for decision-making, information must be provided timely, on purpose and in a convenient form. This can be achieved by using modern 
information technologies within the project management system.

Communications and related to it information are a kind of foundation for coordination actions of project participants [13]. The scheme of information exchange within organization is shown in Fig. 3.

The main consumers of project information are:

- a responsible person for the project stage, who analyze discrepancies between actual and planned work performance indicators and decision-making on the project;

- a customer, in order to be acknowledged of a project work progress;

- suppliers, when there is a need for materials, equipment, etc., which are necessary for work performance;

- designers, when it is necessary to make changes to the design documentation;

- direct executors of works on places.

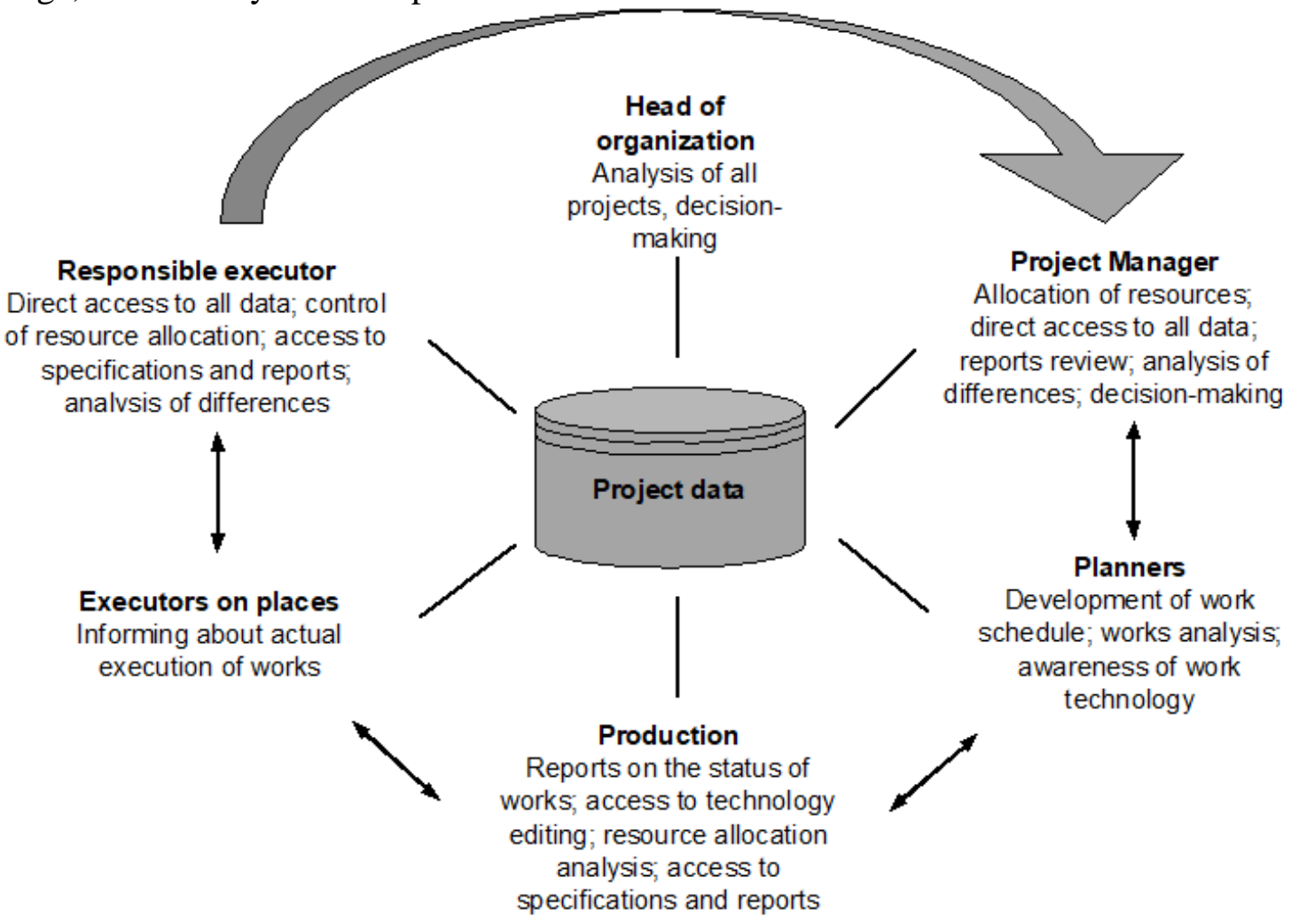

Fig. 3. Information exchange in aviation industry

Communications management provides support for communication system between project participants, a transfer of managerial and reporting information, aimed at ensuring the project objectives achievement. Each project participant must be prepared to interact within the project in accordance with its functional responsibilities. The function of information communication management includes the following processes:

- communication system planning determining the information needs of project participants (information composition, terms and methods of delivery);
- collection and distribution of information - the processes of regular collection and timely delivery of necessary information to project participants;

- reporting on a project progress - processing of actual results of a project in relation with planned one and analysis of trends, forecasting;

- documentation of work progress collection, processing and organization of project documentation storage.

Information collection and distribution systems must meet requirements of different types of communications. For these purposes, automated and non-automated methods of 
collecting, processing and transmitting information can be used [14].

Automated methods envisage usage of computer technologies and modern means of communication to improve efficiency of interaction: e-mail, document flow systems and data archiving [15].

Thus, quality assessment and assurance is one of the most important areas of quality management technology in the life cycle of complex products (aircraft designing).

\section{Quality assurance system in technological process}

Computer-aided design systems, decision-making systems (expert systems) and data management systems play a key role in forming of a technological project process.

In general, a process of functioning of an expert system can be represented as follows. A user, who wants to get necessary information, sends a request to an expert system through a user interface; a solver, using a knowledge base, generates and gives a user an appropriate recommendation, explaining course of his reasoning through subsystem of his explanations.

A special feature of quality management technology within IPI (CALS) concept, as mentioned above, is ability to use electronic data created during various company's processes compounded for quality management tasks. This also applies to a design stage of a complex knowledge-intensive product life cycle.

Availability and constant replenishment of information data in process of developing a technical system and developing a technological project, creates preconditions for successful implementation of additional tools to measure quality of design solutions and quality assurance. In its turn, obtaining through additional assessment tools and ensuring quality of technical systems projects, and then technical systems themselves, significantly increase efficiency and reliability of made decisions on future of a project or product [16].

As mentioned previously, the quality assurance system of the technological project should not be limited only to project management, but should also ensure the quality of the technological project itself. For these purposes, it is proposed to build a subsystem into a design system, the main elements of which will be:

- a technological decisions' formation system;

- a technological solutions' assessment system;

- a decision-making system;

- a communication system.

A schematic diagram of such a quality assurance system of technological project is shown in Fig.4.

Thus, analysis of literature sources while creating a technological project showed that all modern aviation companies are actively implementing CALS / IPI technologies concept, which potentially allows significantly accelerating designing processes and more effectively managing them [14].

In order to move to quality assurance of the technological project in terms of CALS / IPI technologies, it is necessary to carry out development of : modern automated systems for synthesis and analysis of created technological project; technological knowledge bases and expert systems that allow to quickly provide designers with new and reliable information about technological achievements; automated decision-making systems that allow optimizing technological decision-making for each level and stage of a life cycle of technological project; automated configuration management systems of technological project; automated systems of control, management and provision of technological solutions and technological documentation; automated simulation systems, communication management systems for technological design.

\section{port}

Heterogeneous application sup-

Some IMA programs are developed from scratch, there are many existing applications in federated systems. These programs can be developed in different programming languages and use different scheduling models, but you may still need to communicate with each other in an IMA environment. Wind River has addressed this need by supporting diverse programs running in separate ARINC 
sections. This allows the Ada application, which uses the Ravenscar limited task profile, to run on top of the VxWorks 653 operating system along with others. Similarly, the FACE confirmer and the POSIX- conformant7 program can work in separate partitions, and the connection between these two inhomogeneous programs can be implemented using ARINC 653 ports (Fig. 5).

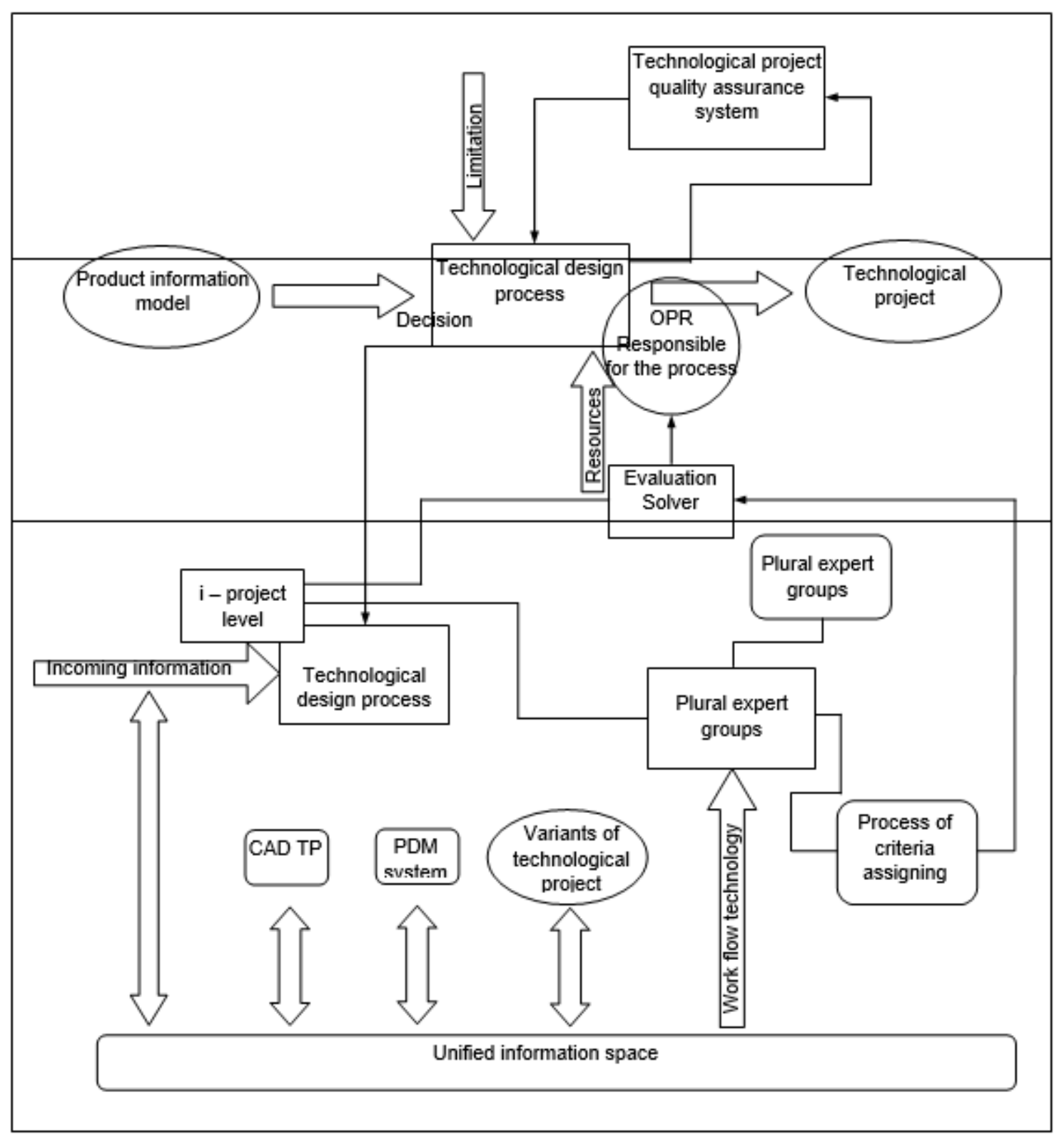

Fig. 4. Schematic diagram of quality assurance system of technological project in aviation industry

Thanks to the availability of multi-core processors with hardware virtualization support, IMA platforms offer an additional path of development that allows you to run multiple operating environments (referred to as guest operating systems or GOS). These GOS provide a number of options in which it would previously be considered difficult or impossible to achieve a sufficiently safe operation.
These configurations may include the use of low-security certification environments, such as a commercial environment or a self-implemented Linux environment, to address systems such as in-flight entertainment, galley management, and other similar aircraft systems. Another potential use of multicore and virtualization is to host legacy OS environments (COTS or proprietary environments) to 
allow application reuse, and to serve as a bridge of assets for platform migration to further reduce the risks and costs introduced by rewriting much of these environments and programs simultaneously. VxWorks 653
Platform, a multi-core edition, opens the door to these and other capabilities for developers through the use of multi-core processors and their capabilities.

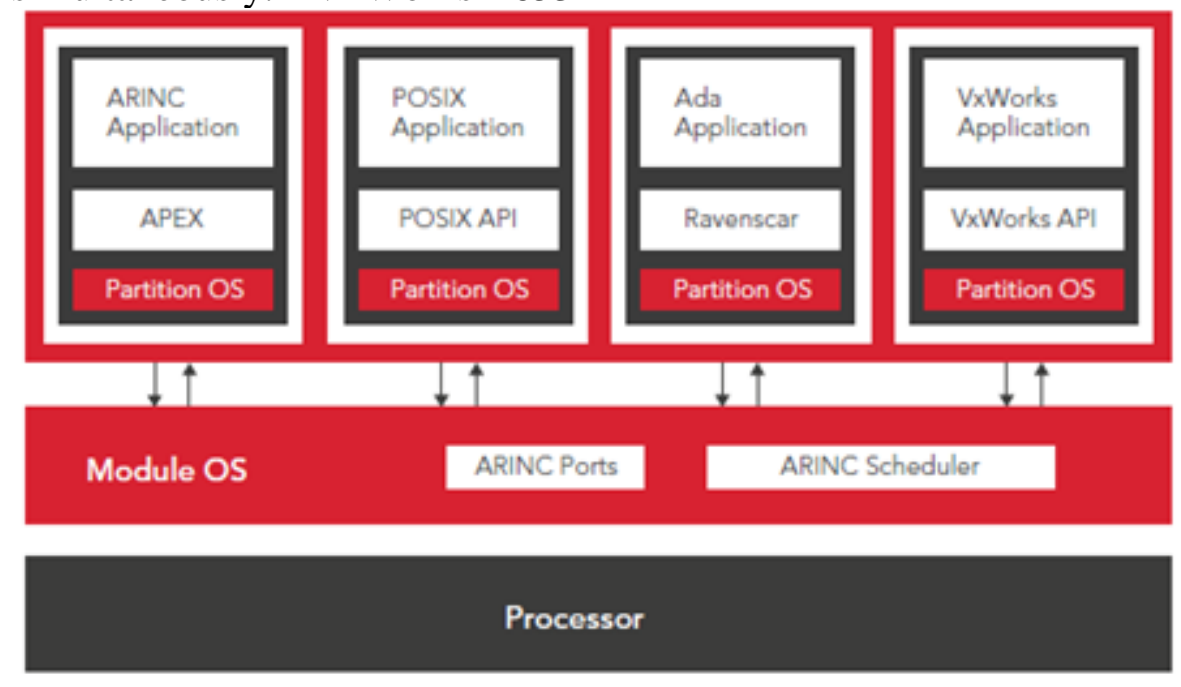

Fig. 5. VxWorks 653 application support

The ARINC 653 architecture ensures resource availability through the use of system configuration records and partitions (IMA). The system configuration entry defines the capabilities and capabilities of the IMA platform and links, and validates individual partition configuration entries. The partition configuration entries define the characteristics of each OEM application in terms of memory requirements, processor requirements, and ARINC port usage. This scheme allows the system integrator to ensure that the requirements of the programs meet the performance of the platform and that individual programs do not exceed the resources allocated to them. Therefore, the goal is to allow the configuration of IMA programs developed by one or more hardware vendors on a common IMA platform that is configured by the system integrator.

The technical features of ARINC 653 provide a high-level definition of the structure and content of configuration records, and implements RTOS.

After all, an example of an XML-based configuration. VxWorks 653 uses the process:

- when initializing the boot systems, download the code of the OS module and record the configuration of systems and partitions;

- the OS module initializes itself by running its own subsystems;

- the OS module loads the program section and their programs.

We result in individual programs and subsystems being developed separately and then integrated into the target file system.

The development process provides a military format configuration of the OS module, and the configuration system and partition records a binary image from additional partitions. Individual individual programs can also be updated without requiring changes to the OS module configuration.

The process, called independent communication and download (IBLL), reduces change change by providing a constant environment for uptime. This process also fully implements the objectives set out in RTCA DO-297 / EUROCAE ED-124, (IMA), "Development and Certification Guidelines 8". Configuration systems and partitions can be replaced without the use of all programs or platforms, which reduces the analysis of the impact of the system integrator when upgrading and modifying an existing system. This results in significantly less recertification 
efforts and more flexibility for vendors and system integrators. VxWorks 653 extends XML-based configurations to provide application developers, platform providers, and system integrators with a complete and skilled set of tools combined with data files to create and initialize IMA platforms.

The tools used to build configuration records in VxWorks 653 generate a duplicate data file with an XML data configuration, a tool that is easier to use and therefore easier to define than other implementations. They are often embedded in common mechanisms, such as the C compiler, to create military configuration data for system use.

\section{Conclusions}

Therefore, quality assurance system of technological project should not be limited only to project management, but should also ensure quality of technological project itself. Thus, we set the task of implementing quality assurance subsystem in technological design, which will significantly improve quality of technological project itself. For these purposes, it is proposed to integrate a project quality assurance subsystem into technological design system on stages of design. The main elements of such a system will be: technological decisions formation system; a technological solutions assessment system; a decision-making system; a communication system.

The platform not only increases developer productivity, but also ensures that certification complexity and effort do not affect developers. Uneven support for ARINC 653, Ada, POSIX, FACE, and VxWorks in IMA helps maximize software reuse and migration VxWorks 653. With the VxWorks 653 platform, a multi-core edition, this feature now extends to legacy platforms and OS environments, using multi-core processors and hardware virtualization that serve as a bridge to move both integrated platforms and IMA. The avionics industry is in the midst of a significant transition to IMA, even though the constant development of IMA architectures and standards poses challenges for standardization organizations, manufacturers, and retailers. VxWorks 653 Platform is an integrated device software platform that combines standardized COTS RTOS and all the tools needed to successfully develop security-compliant IMA programs.

\section{References}

1. Konakhovych H., Kozlyuk I., Kovalenko Y. Specificity of optimization of performance indicators of technical operation and updating of radio electronic systems of aircraft. System research and information technologies, 2020. - №. 3. - P. 41-54.

2. Kovalenko $Y$., Konakhovych $H$., Kozlyuk I. Specificity of optimization of performance indicators of technical operation and updating of radio electronic systems of aircraft. International Journal of Engineering Research and Applications (IJERA). - Vol.10 (09), 2020. - P. 48-58.

3. Kozlyuk I., Kovalenko Y. Functional bases of the software development and operation in avionics. Problems of Informatization and Management, 2020. - № 63. - P. 49-63.

4. Kovalenko Y., Kozlyuk I. Implementation of the integrated modular avionics application development complex according to the ARINC653 standard. The Bulletin of Zaporizhzhia National University. Physical and mathematical Sciences, 2020.№ 2.

5. Kozletsov, A., Reshetnikov, I. Modern methods of organizing data exchange with control systems. Information Technologies in Design and Production, 2010. - № 2. - P. 17-23.

6. Kopylov, Yu., Gordienko, E. Actual directions of development and improvement of CAD systems technological processes. The Bulletin of Voronezh State Technical University, 2011. - № 112. - P. 26-28.

7. Fox, A., Pratt, M.J. Applications of Computational Geometry in Mechanical Engineering Design and Manufacture. - M.: Mir, 1982. - P. 28-36.

8. Madanov, A., Gismetulin, A., Vershilkin, M. Software algorithm for collecting data on a cutting tool from CAMsystem NX files. Prospects for the development of science and education, Part III. - M: AR-Consult, 2014. - P. 54-55. 
9. Madanov, A. Development of automation tools for preparing control programs in NX environment. XXI Tupolev readings (school of young scientists): International Youth Scientific Conference. Collection of reports. - Kazan: Folio, 2015. P. 75-78.

10. Dryanushkin, A. Methodologies of processing templates creation and machine tool library for developing control programs in the NX 7.5 environment. The Bulletin of Samara Scientific Center of the Russian Academy of Sciences, 2013. - Vol. 15. - № 4 (3). - P. 683-687.

11. Samsonov, $O$. Development of information support for design and modeling of assembly processes. The Bulletin of Samara Scientific Center of the Russian Academy of Sciences, 2014. - Vol.16. - № 1 (5). - P.1601-1608.

12. Samsonov, $O$. Design of assembly technology of aircraft products in digital information and software environment. Assembly in mechanical engineering, instrument engineering, 2008. - № 6. - P. 311.

13. Kalabin, $V$. Basic data management as one of the tasks of integrating corporate management systems. Business Informatics, 2007. - № 1. - P. 19-28.

14. Lee K. Principles of CAD / CAM / CAE Systems, Addison Wesley, 1999.

15. Kuprikov, M. Automation of design works as a fundamental factor in quality assurance of a life cycle of products in mechanical engineering. New Information Technologies. Abstracts of X anniversary of the International Student School-Seminar. M.: MGIEM, 2002. - P. 48-53.

16. White, A. Magic Quadrant for Master Data Management of Product Data. Research Note G00158359. - Gartner, 2008

\section{Коваленко Ю.Б., Козлюк І.О.}

\section{ПРОЕКТУВАННЯ ТЕХНОЛОГІЧНИХ ПРОЦЕСІВ ІНФОРМАЦЙНОӤ ПІДТРИ- МКИ ПРИЙНЯТТЯ РІШЕНЬ ІНТЕГРОВАНОЇ МОДУЛЬНОЇ АВІОНІКИ}

Досвід світових лідерів галузі показує, що ключовими факторами в досягненні ефективної і продуктивної організаиї праці є реорганізація схеми інформаційних потоків, оптимізація організаційної структури компаній і схеми управління виробничими процесами. При ичьому складається єдиний інформаційний простір, в якому інформаџійна модель продукту створюється і підтримується протягом усього його життєвого ичилу. Для сучасного авіабудування однією з важливих і актуальних завдань є автоматизація проектування технологічних процесів. Вирішення цього завдання дасть можливість підвищити ефективність технологічного проектування $i$ здійснити технологічне планування виробничих ресурсів. Інтегрована модульна авіоніка (IMA) призводить до зменшення підсистем, які мають меншу вагу, займають менше місия і споживання енергії (SWaP). Ряд дослідницьких програм прагнули визначити архітектури IMA, $i$, хоча вони різняться за своїми підходами, вони поділяють одні й ті ж високорівневі иілі. Загальні підсистеми обробки, тобто архітектура IMA повинна дозволити декільком додаткам спільно використовувати і повторно використовувати ті ж обчислювальні ресурси, тому необхідно розкладати менше підсистем, щуо призводить до більш ефективного використання системних ресурсів $і$ залишає місце для майбутнього розширення. Архітектура ІМА повинна ізолювати додаток не тільки від базової архітектури шини, але $i$ від базової апаратної архітектури, така практика розширює можливості перенесення додатків між різними платформами, а також дозволяє вводити нове обладнання для заміни застарілих архітектур; архітектура IМА повинна дозволяти повторне використання успадкованого коду. Це скорочує час розробки, надаючи метод повторного розгортання існуючих додатків без серйозних модифікаџій; архітектура IМА повинна зменшувати вартість змін так як ІМА полегшує повторне використання, так і тому, щь, 
відокремлюючи складові частини платформи, які виконуються на одному прочесорі, спрощується аналіз впливу, знижуючи витрати на повторне тестування. ІМА полегшує підтримку додатків з постійно зростаючими функиіональними можливостями. IМА використовує технологію багатоядерних проиесорів для полегшення таких різноманітних додатків, як введення-виведення; виконання декількох розрізнених операчійних середовищ, таких як Linих, що не належать до COTS, за допомогою віртуалізації.

Ключові слова: інформаційні системи, підтримка прийняття рімень, проекти в авіаційній галузі, автоматизована система проектування, технологічний процес, інтегрована модульна авіоніка.

\section{Kovalenko Yu.B., Kozlyuk I.O.}

\section{DESIGNING OF TECHNOLOGICAL PROCESSES OF DECISION-MAKING SUP- PORT INFORMATION SYSTEM IN INTEGRATED MODULAR AVIONICS}

The experience of world leaders in the industry shows that the key factors in achieving efficient and productive work organization are the reorganization of the information flow scheme, the optimization of the organizational structure of companies and the scheme of production process management. This creates a single information space in which the information model of the product is created and maintained throughout its life cycle. For modern aircraft construction one of the important and urgent tasks is the automation of technological processes. The solution of this problem will give the chance to increase efficiency of technological designing and to carry out technological planning of production resources. Integrated modular avionics (IMA) allows you to reduce subsystems that are smaller in weight, take up less space and consume energy (SWaP). IMA makes it possible to isolate the application not only from the basic bus architecture, but also from the basic hardware architecture, this practice expands the possibilities of transferring applications between different platforms, which allows you to introduce new equipment to replace obsolete architectures. Therefore, IMA should allow multiple applications to share, use, and access the same computing resources at the same time, so fewer subsystems need to be deployed, resulting in more efficient use of system resources and room for future expansion. IMA allows the reuse of inherited code. This reduces development time by providing a method of redeploying existing applications without major modifications. IMA reduces replacement costs because IMA facilitates reuse and because separating the components of the platform that run on a single processor simplifies impact analysis by reducing the cost of retesting. IMA makes it easy to support applications with ever-increasing functionality. IMA uses multi-core processor technology to facilitate a variety of applications such as I / O; running multiple disparate operating environments, such as non-COTS Linux, through virtualization.

Keywords: information systems, decision-making support, project in the aviation industry, automated design system, technological process, integrated modular avionics. 